\title{
SIGNIFICANCE OF DIGITAL COMMUNICATION CHANNELS FOR TOURISM PROVIDERS IN HOLIDAY REGIONS
}

\author{
Christian ENZ ${ }^{a}$, Dagmar ŠKODOVÁ PARMOVÁa \\ ${ }^{a}$ Faculty of Economics, University of South Bohemia Studentská 1337005 České Budějovice, Czech \\ Republic, e-mail: enzchr00@jcu.cz
}

Cite this article: Enz, C. Škodová Parmová, D. (2020). Importance of digital communication channels for tourism providers in holiday regions. Deturope. 12(2): 140-165.

\begin{abstract}
This paper deals with the importance of print products in SME corporate communications. To this end, the interest of customers of a German tour operator belonging to the SME in printed travel literature is analyzed. For this purpose, two independent samples with $n=1,500$ each are examined. An influence of the characteristics age, gender, place of residence can be proven. In each case, the influence is of medium strength. Logistic regression is then used to try to explain better the consumption of printed travel literature. In addition, the economic importance of a customer, which was determined during a customer segmentation, is included. It becomes clear that the place of residence with age and customer segment are of particular importance. This shows that print cannot be dispensed with in corporate communications in certain target groups. It also becomes clear that optimal coordination of corporate communications can be developed into a competitive advantage for SMEs. Namely, when a target group that differs from the overall population is reached more efficiently than by national or international competitors.
\end{abstract}

Keywords: SME, Marketing, Communications, Tourism

\section{INTRODUCTION}

Owner-managed small and medium-sized enterprises make an enormous economic contribution (Walter, 2017c, p. 57). After all, 85 percent of companies in the European Union are run by owner families. At the same time, they provide 60 percent of jobs in the private sector (Walter, 2017a, p. 4). In tourism, the group of owner-managed SMEs also has an outstanding position throughout Europe. In Tyrol, for example, $98.4 \%$ of the hotel industry is family-owned (Weber \& Kühne, 2015). In Germany, tourism is also largely characterized by SMEs. This is ensured by 2,300 tour operators, almost 4,000 bus companies, 11,000 travel agencies, and more than 222,000 companies in the hotel and catering industry (Weber, Göhlich, Schröer, \& Engel, 2017). Against this background, Zehrer (2020) speaks about a pronounced fragmentation of tourism. To develop still market power, tourism SMEs regularly come together in cooperations at the level of a destination - albeit very differently structured cooperations (Wilke, 2009b, p. 26 ff.). This seems to be based on future expectations. According to Eller, Glowka \& Zehrer (2020), small and medium-sized tourism enterprises were already confronted with tougher 
competition within the industry before the Corona pandemic (Walter, 2017b, p. 6). However, Pichler (2020) adds, the potential of cooperation is still underestimated. Yet small and mediumsized enterprises are also offered marketing and communication channels in this way that they would not be able to tap individually (Wilke, 2009c, p. 55 f.).

According to Wiener (2020), the tourism industry already was in crisis before the Corona pandemic and will continue to be so after the emergency (Wilke, 2009a). The same is due to the economic and social environment in which companies operate today. This is increasingly characterized by complexity and dynamics (Spielhagen, 1996). Ultimately, this ensures that in the battle for the limited clientele of holidaymakers, regional SMEs and international corporations are pitted against each other (Wilke, 2009a). The result is a persistent, destructive competition that leads to increased market concentration. During this, small tourism offers are increasingly disappearing (Will, 2018, p. 29). Škodová Parmová et al. (2018) also see threatened the existence of tourism offers that do not succeed in conveying a USP (Zehrer, 2020).

Against this backdrop, if tourism SMEs want to assert themselves in the market in the long term, they must optimize their processes to increase their competitiveness (Hoffmann, Lennerts, Schmitz, Stölzle, \& Uebernickel, 2016; Pfeil, 2016, 332 f; Rauch, 2019, p. 186). Marketing communication is of particular importance in this context. This management tool allows existing or potential visitors of a holiday destination to be shown how precisely their personal requirements or needs can be met (Zerfaß, 2006, p. 57). In essence, it is about activating target groups effectively and efficiently through strategic planning (Bassewitz \& Ritter, 2001, p. 708). According to Kormanova (2015), the degree of effectiveness achieved here has a direct influence on the operating result and thus high entrepreneurial relevance (Pfannstiel, Da-Cruz, \& Rederer, 2020, p. 318).

This is why the field of corporate communication has already been the subject of much academic work. A variety of approaches exist on this long ago (Heister, 1962; Helfrich, 2016; Zerfaß, Bentele, Schwalbach, \& Sherzada-Rohs, 2018). However, these always aim to address the statistical average customer. They are modeled from demographic and statistical data as well as focus tests and customer feedback (Pfohl \& Arnold, 2006, p. 142). However, this concept, which is often found traditionally, is subject to ongoing criticism, because it does not appreciate the uniqueness of the individual sufficiently (Philipp, 2017, p. 72). Moreover, the traditional concepts always require the use of all known instruments of marketing communication. 
Given the individual needs of tourists and regionally different media infrastructure, it might be possible to develop corporate communication of tourism SMEs into a competitive advantage. This would require putting together a locally more efficient communication mix compared to national or international campaigns (Zerfaß \& Piwinger, 2014, p. 28).

\section{THEORETICAL BACKGROUND}

The aim of this study is to determine, whether tourism SMEs can win customers more efficiently through individual corporate communication than with generally valid communication concepts. This is of particular interest because decisions in SMEs are often not made rationally. Also, the business management competence of the decision-makers, who are put into function by family structures, is often insufficient (Enz, 2019b, p. 9). In SMEs, this often leads to decisions being made intuitively or not at all. Against this background, Reichard, referring to Zerfaß, Fink \& Winkler, states that SME marketing communication is essentially situational (Reichhard, 2019, p. 79; Zerfaß, Fink, \& Winkler, 2015, p. 49). While there is consensus that the field of corporate communication has experienced a professionalization in recent years (Hetze, Bögel, Emde, Bekmeier-Feuerhahn, \& Glock, 2019, p. 259; Johann, 2020, p. 147), this development is traditionally found in large companies, corporations and organizations (Lützler, 2007, p. 127; Mast \& Spachmann, 2005, p. 15; Zerfaß \& Pleil, 2017). In contrast, Friedrichs and Winkler identify increasing tendencies towards professionalization in the field of marketing communication even among small and medium-sized enterprises (Friedrichs \& Winkelmann-Fietz, 2020, 25 ff; Winkler, 2020, p. 3). This development can be explained by the now generally accepted realization that strategic communication is indispensable for successful competitive positioning (Falkheimer et al., 2016; Kiesenbauer, 2018, p. 1; Winkler, 2020, p. 61).

Although there is an agreement that corporate communication is also a success factor for SMEs (Müller, 2011, p. 11; Zerfaß, 2014, p. 22), only a few studies have so far dealt with the specific prerequisites or the different nature of SME communication (Enz, 2020a; Winkler, 2020, p. 61). Although Fischbach \& Mack already criticized the lack of scientific examination of professional corporate communication in SMEs in 2008 (Fischbach \& Mack, 2008, p. 36), research, as Moog \& Witt agree with Fischbach \& Mack, has so far focused primarily on purely business aspects or topics from marketing (Fischbach \& Mack, 2008, 35 f; Moog \& Witt, 2013). While Fischbach \& Mack attribute this fact to the long tradition of business administration compared to communication research (Fischbach \& Mack, 2008, p. 36), the author of this paper 
see the reason primarily lacking research funding. Corporate communication is predominantly seen as a cost factor (Heemsoth, 2019, p. 227). SMEs can indeed be considered innovative and often work successfully with universities. However, SMEs prefer to use their budgets in research projects related to their core business searching for innovations (Fuka, Vrchota, \& Rolínek, 2018; Kamerar, 2016; Vrchota, Volek, \& Novotná, 2019).

Interest in strategic marketing communication and frugality are not contradictory. According to Johann, a communicated message can also be regarded as a business asset to which a monetary value can be attributed (Johann, 2020, 98 ff.). Thus, the idea identified by Škodová Parmová et al. of countering global competition with regional strategies could also be transferred to the discipline of marketing communication (Škodová Parmová, Líšková, \& Kain, 2018). Besides, Enz notes that different marketing channels are available in different regions. These also have regionally different effects on the opinion formation of target groups. Thus, with a communication mix, that is adapted optimally to regional conditions, a competitive advantage can be developed for SMEs operating regionally compared to supraregional competitors oriented towards the average customer (Enz, 2019a, p. 190).

\section{Definition SME}

Dobošová et al. agree with Bondareva \& Zatrochová, that there is consensus that SMEs are the basis of a stable and successful market economy (Bondareva \& Zatrochová, 2014; Dobošová, Hupková, Beňuš, Mihálová, \& Synetska, 2020, p. 21). However, the understanding of which companies belong to the SME category is inconsistent. As early as 1991, Kosminder has registered over 200 approaches describing SMEs (Kosmider, 1991). Against this background, the idea of an expedient definition in individual cases has prevailed over a generally valid definition (Becker \& Ulrich, 2011, 18 f.). Both qualitative and quantitative criteria can be used (Botzkowski, 2017, p. 39). This paper considers a company to be an SME if it meets the criteria set by the European Union. Accordingly, a company is considered an SME, if it employs a maximum of 250 employees and has an annual turnover of no more than 50 million euros (Enz, 2020b, p. 29).

\section{Definition of marketing communication}

Ternés et al. see the task of marketing communication as influencing the decisions of members of a defined target group in the interest of the company (Ternès, Klenke, Jerusel, \& Schmidtbleicher, 2017). It is therefore a matter of creating the desired perception about products 
and services offered or the company as a whole. To this end, opinions must be anchored in the minds of customers and non-customers, reinforced or changed in the interests of the company (Kilian, 2019, p. 63). Against this background, marketing communication is to be understood as an integrating management process. This includes all internal and external communication instruments. Bruhn also speaks of integrated communication in this context (Bruhn, 2016, p. 107). In this context, Bruhn argues that a message is perceived more concisely the more it is conveyed similarly on different channels (Bruhn, 2009, p. 46).

However, marketing communication is undergoing major changes. This is due to new technologies that are changing the media landscape (Scheu \& Schedifka, 2018, 178 f.). Volkswagen AG, for example, spends almost 50 percent of its media budget on digital communication channels in 2020. In 2015, the share was still 25 percent. At the same time, the shift is linked to the expectation of greater efficiency. Marketing efficiency is to be increased by 30 percent. This goal has to be achieved even though the use of new communication channels requires about five times more campaign elements than before (Volkswagen AG, 2018). To achieve such effects, globally operating groups can streamline their processes. Volkswagen's approach is exemplary for the current implementation of marketing communication. By contrast, it is not conceivable for SMEs to use additional communication channels in a costneutral way by simply regrouping (Enz, 2020b).

Tourism SMEs have to deal with two challenges at the same time. On the one hand, increasing competition results in growing cost pressure (Beritelli \& Bieger, 2020, p. 494). On the other hand, new communication channels, especially social networks such as Instagram or Facebook, are gaining significant influence on tourists and their usage behaviour regarding tourism offers (Kreuter, 2020, p. 48). To avoid higher communication expenses, tourism providers have increasingly shifted their budgets towards new digital communication channels in recent years.

This is expressed, for example, in ADAC Motorwelt, the club magazine of Germany's largest automobile club. In 2010, it was published a total of ten times with a circulation of 14.5 million copies. For many pages, classified ads were the dominant graphic element. Small and mediumsized hotels and accommodation providers advertised for customers. So did tour providers or further education providers such as skiing or sailing schools (Tieschky, 2010). Since 2020, Motorwelt has been published only four times a calendar year. The circulation has dropped to 5 million (ADAC Newsroom, 2020). There are no more tourist classifieds in the ADAC Motorwelt, after a serious decline in the number of advertisements in recent years. 
This trend is also reflected in the publications of tour operators and hotels. For example, the majority of the approximately 2,500 tour operators on the German market still rely on catalog sales. Due to the high printing and logistics costs as well as a low booking rate per catalog, the use is becoming increasingly restrictive (Herrmann \& Wetzel, 2018, 33 f.). Today, only 30\% of sales in travel agencies are based on consultation with a printed catalog (Graefe, 2017). In contrast, the use of electronic catalogs increased by $27.5 \%$ in the last 3 to 5 years alone (Statista Research Department, 2015). At the same time, the number of providers who no longer provide printed information is increasing (Beetz, 2016; Visit Sweden GmbH, 2020). The tourism industry thus is following a trend from the mail-order business. For example, the large German mail-order company Neckermann stopped producing catalogs in 2012, and the Hamburg-based Otto-Versand followed suit in 2018 (Voß, 2018).

The present research work is intended to clarify whether SME's renunciation of print communication in tourism is a sensible business consequence. This would be the case if customers and potential consumers could be reached just as effectively with other communication channels - at lower costs simultaneously.

\section{DATA AND METHODS}

This paper examines the behavior of the customers of a medium-sized German tour operator. For this purpose, the company carried out an existing customer promotion. In the period from 1st to 28th February 2020, 1,500 existing customers could order actually priced travel information free of charge. The customers could choose between travel guides and illustrated books on travel destinations worldwide. In addition, customers could choose between the classic printed version and a digital edition for smartphones, tablets or computers. The customer gifts had a merchandise value of up to 25 euros, which provided an incentive to participate in the campaign. In fact, the interest in the retrievable publications was so great that the contingent provided was used up after 2.5 weeks and the measure had to be ended prematurely.

\section{Analysis of customer potential}

The tour operator under review belongs to the SME group. As of 31st December 2019, it had a base of approximately 10,000 active customers of all ages. It should be noted that the preferences of individual tourism offers differ greatly depending on the age of the consumer (Golder, Jans, Tschöpe, \& Herzog, 2017, 3 f.). Against this background, it is important to clarify 
whether the consumption of printed travel information is also age-dependent. This results in the first hypothesis to be tested:

H1: There is no dependency between the consumption of printed travel information and the age of the consumer.

The customer potential can be selected according to other sociodemographic data in addition to age. An important factor for the present research work is the place of residence. Aufner et al. (2020) have shown that individual media use is influenced by location (Aufner et al., 2020, p. 347). This is consistent with Döweling, who could already prove in 2019 that internet use increases with the size of the place of residence (Döweling, 2019, p. 67). From this, the question can be derived, whether the consumption of travel literature differs in rural and urban regions. However, different concepts exist to delineate urban and provincial areas (Albrecht \& Walther, 2017, 6 ff.). According to Albrecht, a differentiation can be made because of population density and other characteristics such as settlement density and transport area (Albrecht \& Walther, 2017, p. 9). However, differentiation can also be made based on other aspects, such as the function of a place in the context of the central place concept (Miosga et al., 2020, p. 6). In addition, there is not even a binding definition of the different types of places of residence (Danielzyk, 2017, p. 11). In the economic-geographical context, the terms village, market, small town, medium center, upper center, and the large city can be found. To categorize neatly the available data, a differentiation is made in this paper because of the number of inhabitants of the respective places of residence. The author follows the definition of the German Federal Statistical Office. In accordance with international practice, this defines a city as a large city, if it has more than 100,000 inhabitants (destatis.de, 2011). Based on these data, it is to be clarified whether the place of residence influences the consumption of printed travel information. This results in the hypothesis to be tested:

H2: Consumption of printed travel information is independent of the place of residence.

Besides age and place of residence, gender could also have an effect on interest in printed travel literature. After all, men are more open to new technologies than women (Störk-Biber, Hampel, Kropp, \& Zwick, 2020, p. 29). In addition, younger people are more tech-savvy than older people (Deutsche Akademie der Technikwissenschaften \& Körber Stiftung, 2020, p. 13). In this context, it should be considered that electronic travel literature might appeal more to a tech-savvy target group, as it combines information with modern technology. In addition, 
digital travel information offers new possibilities such as 360-degree panoramas, virtual tours, etc. Considering this perspective, the influence of gender on the consumption of printed travel literature is to be examined. This will be done within the framework of a hypothesis test:

H3: Consumption of printed travel information is independent of gender.

In order to clarify the research, questions formulated, the participants of the described existing customer campaign are analyzed. This involves a total of 1,500 data records. These contain the age of the participant, the specification of the place of residence, the gender as well as a characteristic, whether the participant is an A, B, or C customer. This attribute is assigned because of the turnover within the last three years.

To identify possible special features within the customer group interested in printed travel information, a comparison group is necessary. For this purpose, a control group with 1,553 data records was formed from the customer base. These comparison customers were determined in a random draw. Before starting the data analysis, it is, therefore, necessary to check whether the distribution of the random sample matches the population of the entire customer base. If this were to deviate extremely unintentionally, this would have a negative impact on the significance of the tests.

To check the random sample, a histogram is created over the age distribution using the software R 4.0.3. This shows that the distribution fits the corresponding population.

\section{Figure 1}

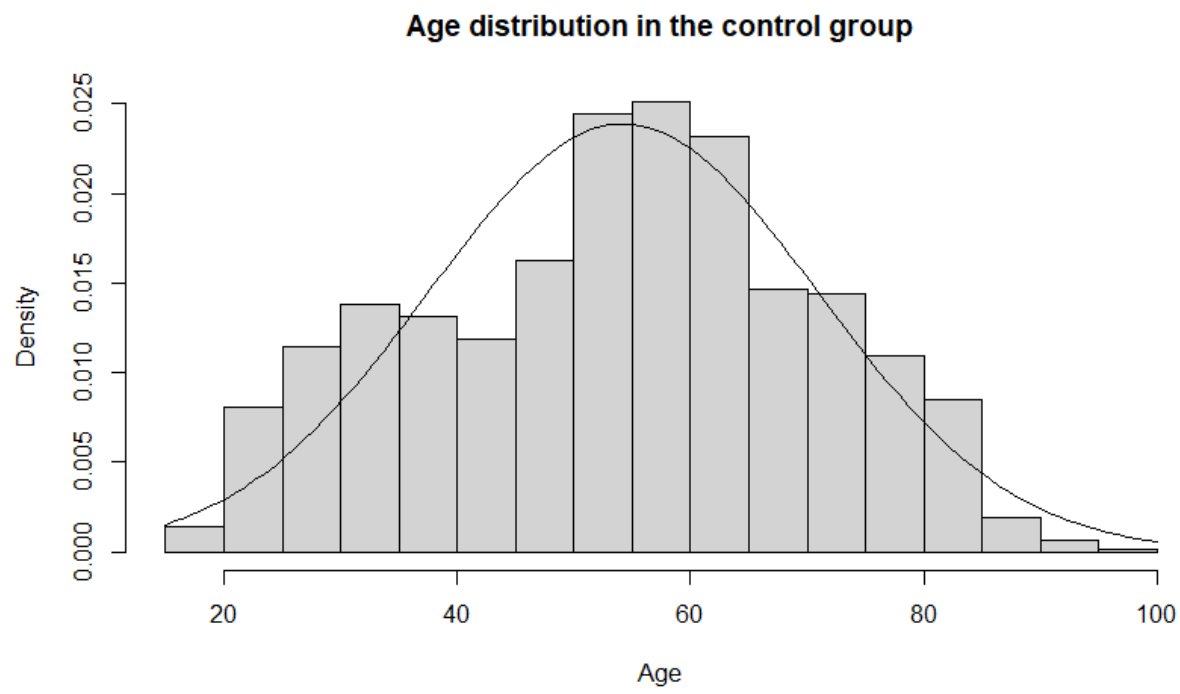




\section{Methods for testing the hypotheses}

Hypothesis $\mathrm{H} 1$ states, that there is no correlation between the consumption of printed travel information and the age of the consumer. It is therefore a matter of examining the mean values of two independent samples for differences. Such an analysis can be carried out using a t-test. This exists in two versions: the simple Student's t-test and the Welch's t-test (Sakai, 2016). According to White et al., the Welch t-test is preferable, if it cannot be ruled out that the mean values differ. The Welch t-test is also preferable, if it cannot be ruled out, that there are different deviations from the normal distribution in the samples, (White, Redford, \& Macdonald, 2019). Against this background, the Welch t-test is used to test hypothesis H1. For the Welch t-test to produce a robust result, two independent samples must be present. In addition, a metrically scaled y-variable is necessary. Furthermore, the y-variable must be normally distributed within the groups. It also needs a normally distributed error term. In contrast to the normal t-test, however, almost equal variances of the y-variables of the two groups are not necessary (Walther, 2019). The test shows that all requirements for the Welch t-test are fulfilled.

The Welch t-test is carried out within the framework of this research work with the software $\mathrm{R}$ 4.0.3. Basically, an analysis of the two samples shows that the group of purchasers of travel literature is on average significantly older than the comparison group. This is illustrated in figure 2, which is output by $\mathrm{R}$ using the package ggplot2:

$\begin{array}{lllll}> & \text { \#\#\# } & \text { Test } & \text { Hypothese } & \text { H1 }\end{array}$

$>$ \# Dependence of willingness to order on age

> \# Diagram "Representation of age distribution"

$>$ boxplot(df\$Alter $\sim$ df\$Bestellung) 


\section{Figure 2}

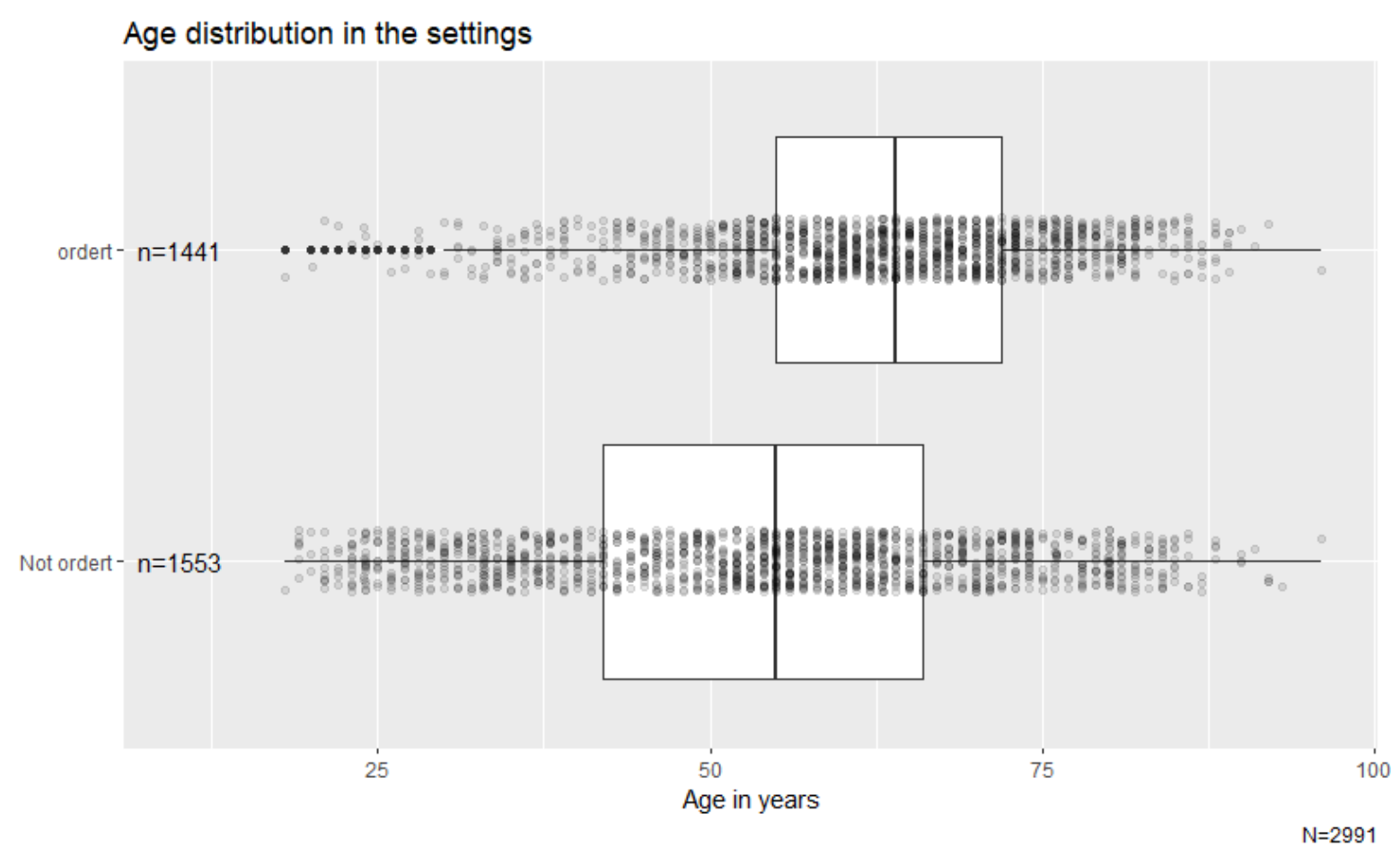

> \#\#\# Test Hypothese H1

$>$ \# Welch-Test

$>$ psych::describeBy(df\$Age, df\$Order)

$>$ t.test $($ df $\$$ Age $\sim$ df $\$$ Order, var.equal=FALSE)

$>$ gplots::plotmeans(df\$Age $\sim$ df\$Order,

$>\quad$ main="Error bar graph $(95 \%-\mathrm{CI}) "$,

$>\quad \mathrm{xlab}=$ "",ylab $=$ "Age in years",

$>\quad y \lim =\mathrm{c}(50,65))$

$>$ effsize::cohen.d(df\$Age $\sim$ df\$Order, na.rm=TRUE, paired=FALSE, pooled=FALSE)

The average age according to participation status differs significantly according to Welch's test $(\mathrm{t}(2881.2)=-16.06, \mathrm{p}<0.001)$, with the group of orderers having an age 8.66 years higher (95\%-CI [7.6, 9.7]). According to Cohen (1992), the effect size is $d=0.68$ and corresponds to a medium effect.

The group of orderers is on average 62.88 years old (median=64, $\mathrm{SD}=12.68$ ), while the group of non-orderers is 54.21 years old (median $=55, \mathrm{SD}=16.69$ ). 


\section{Figure 3}

Error bar graph $(95 \%-\mathrm{Cl})$

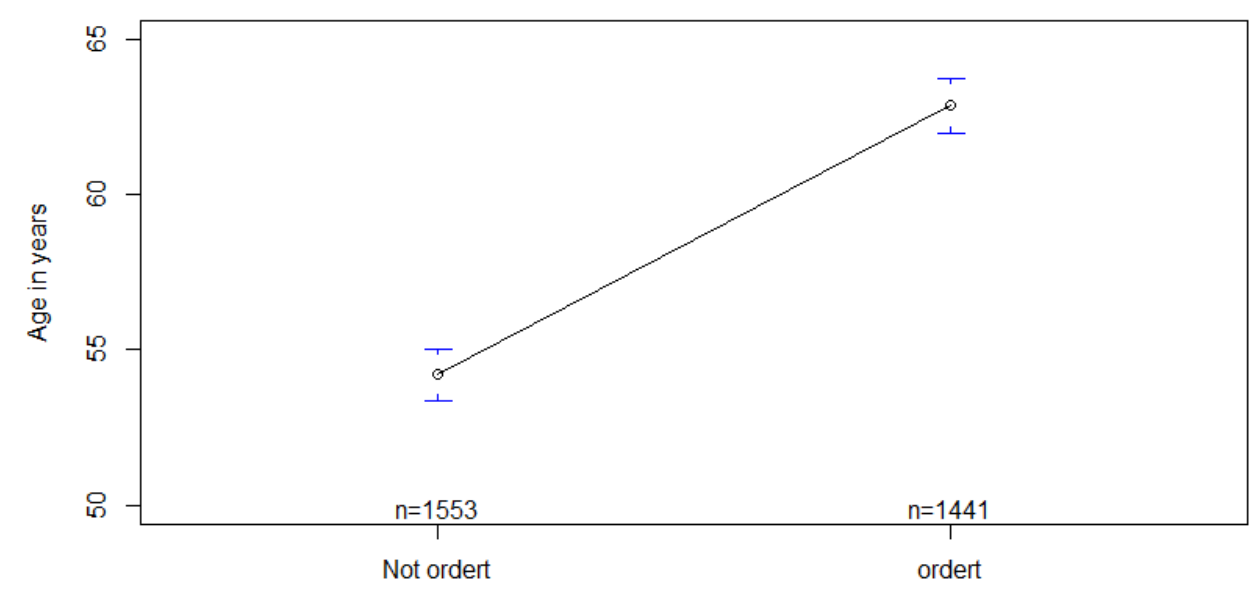

The mean effect is confirmed by the Glass's Delta Test, which was also carried out. This shows a lower value of -0.7572906 and an upper value of -0.6097302 for a $95 \%$ confidence interval.

Thus, it cannot be proven that age and ordering behavior are independent. Consequently, hypothesis $\mathrm{H} 1$ must be rejected.

Another factor influencing ordering behavior could be the place of residence. This is expressed in hypothesis H2. It states that the consumption of printed travel information is independent of the place of residence. According to Schlager, if the stochastic independence of the results of two groups is to be examined, the chi-square test can be applied. The prerequisite is, that the null hypothesis H0 has been accepted (Schlager, 2020, p. 219). If the examined characteristics are not stochastically independent, there is obviously a correlation between the attributes. If the characteristic expresses membership of a group, it can be interpreted as a group difference according to Bortz et al. (Bortz \& Schuster, 2016, p. 137).

In this case, a group characteristic is examined that exists in two forms. The characteristic 'big city' includes the inhabitants of cities with more than 100,000 inhabitants. The characteristic 'non-metropolitan' groups together the inhabitants of regions considered rural for the purposes of this study.

\section{Table 1}

\begin{tabular}{|l|l|l|l|}
\hline & non-metropolitan & big city & sum \\
\hline not ordered & 1060 & 492 & 1552 \\
\hline ordered & 1099 & 344 & 1443 \\
\hline sum & 2159 & 836 & 2995 \\
\hline
\end{tabular}


Table 2

\begin{tabular}{|l|l|l|}
\hline & non-metropolitan & big city \\
\hline not ordered & 1118.787 & 433.2127 \\
\hline ordered & 1040.213 & 402.7873 \\
\hline
\end{tabular}

In both samples, $n>50$ and old values are greater than 5 . Thus, all prerequisites are fulfilled and the chi-square test can be carried out. The distribution in the samples already indicates a difference, as the mosaic diagram created with $\mathrm{R}$ shows:

\#\#\# Hypothesis H2: Dependence of willingness to order on the place of residence

\#Mosaic diagram

$>$ mosaicplot(table(df\$Order, df\$GS))

$>$ addmargins(table(df\$Order, df\$GS))

$>$ barplot(table(df\$Order, df\$GS), beside=TRUE)

\section{Figure 4}

\section{Distribution of place of residence for participation}

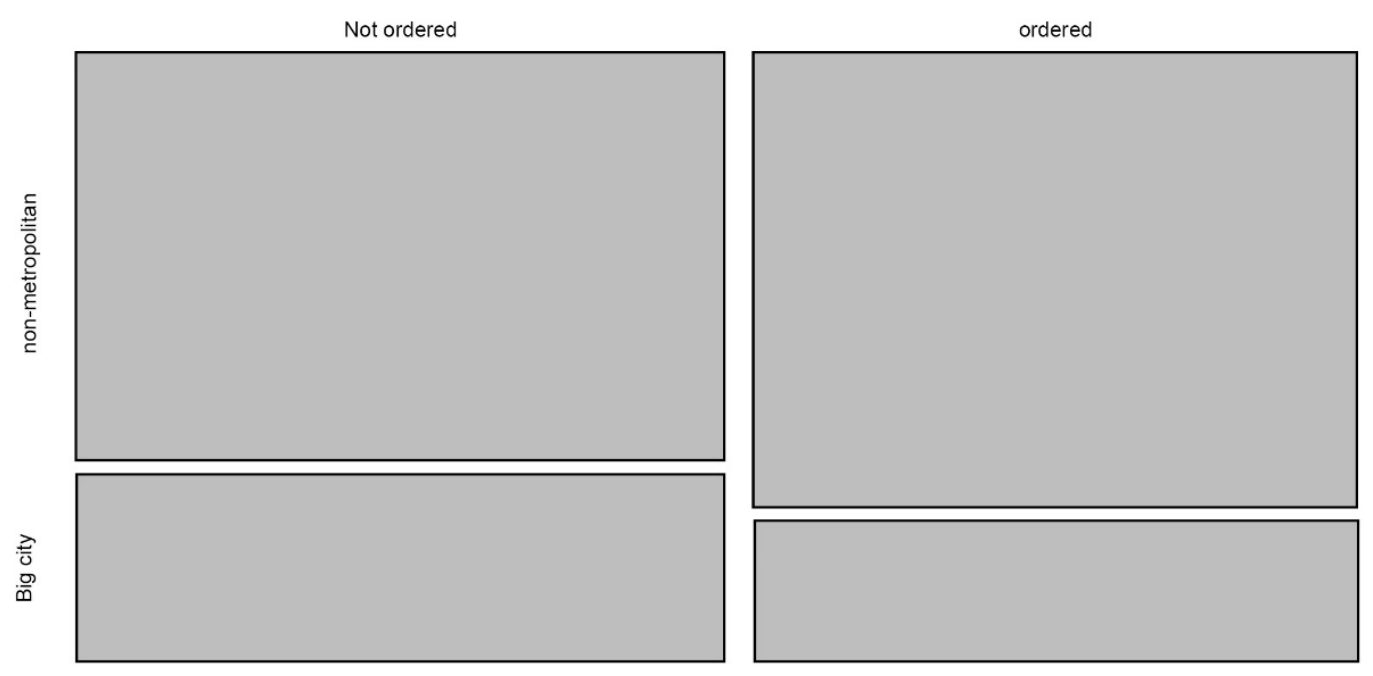

$>$ \#\#\# Hypothesis H2: Dependence of willingness to order on place of residence

$>$ \# Chi-Quadrat-Test

$>($ chiq $1<$ - chisq.test $($ table $($ df $\$$ Order, df $\$$ GS $)))$

$>$ addmargins(table(df\$Order, df\$GS))

$>$ chiq1\$expected 
Performing the chi-squared test yields a P-value of 2.0164-06 $(\mathrm{p}$-value $=0.002016)$ with a test statistic of $22.58(\mathrm{x}$-squared $=22.58)$ and one degree of freedom $(\mathrm{df}=1)$. Thus, the null hypothesis must be rejected. A significant correlation between ordering behavior and place of residence can be assumed.

To measure the strength of this correlation, a derivation of Chi-square is carried out using Cramer's V. This is possible because the underlying cross-tabulation is larger than $2 \times 2$ (Bauer).

$>$ \# Cramers V for Hypothese H2

$>$ library(lsr)

$>$ cramersV((table $($ df $\$$ Order, df $\$$ GS $)))$

The calculation yields a value of 0.3474576 for Cramer's V, which corresponds to a medium correlation (Benning, 2020).

Another group characteristic can be derived from the available data set with the gender of the participants included in the samples.

\section{Table 3}

\begin{tabular}{|l|l|l|l|}
\hline & male & female & sum \\
\hline not ordered & 1009 & 543 & 1552 \\
\hline ordered & 1115 & 383 & 1498 \\
\hline Sum & 2124 & 926 & 3050 \\
\hline
\end{tabular}

Table 4

\begin{tabular}{|l|l|l|}
\hline & male & female \\
\hline not ordered & 1080.803 & 471.1974 \\
\hline ordered & 1043.197 & 454.8026 \\
\hline
\end{tabular}

The prerequisites are tested with $\mathrm{R}$ and the procedures outlined for hypothesis H2. Checking the prerequisites for the chi-square test to test hypothesis $\mathrm{H} 3$ shows that $\mathrm{n}>50$ in both samples. Furthermore, all values are greater than 5. Thus, hypothesis H3 can be tested using the chisquare test. The distribution in the samples also indicates a difference here, as shows the mosaic diagram created with $\mathrm{R}$ : 


\section{Figure 5}

\section{Distribution of participation by gender}

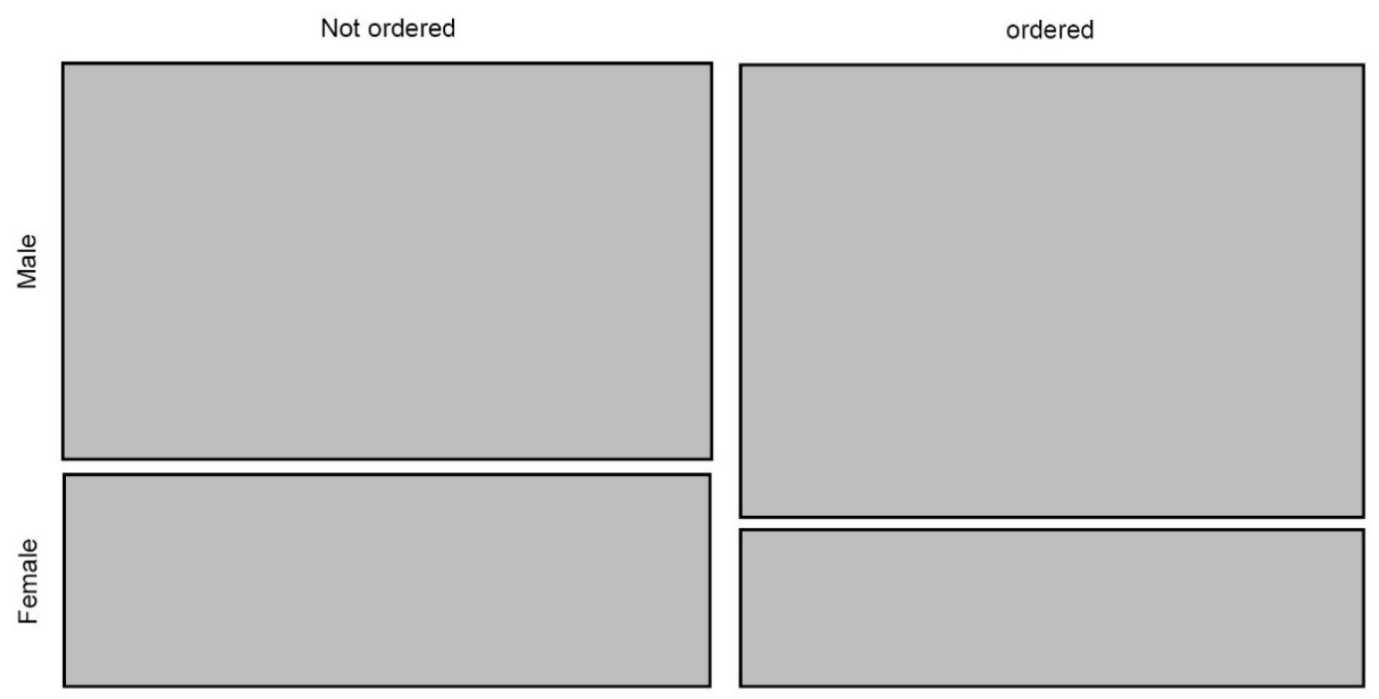

Performing the chi-square test gives a P-value of 1.9484-08 (p-value $=0.000019)$ with a test statistic of $31.546(\mathrm{x}$-squared $=31.546)$ and one degree of freedom $(\mathrm{df}=1)$. Thus, the null hypothesis must be rejected. A significant correlation between ordering behavior and place of residence can be assumed.

The strength of the correlation is determined by the help of Cramer's V. The prerequisite of a cross-table larger than $2 \times 2$ is given. Using calculation, a value of 0.08682851 can be determined for Cramer's V. This means that the value is below 0.2, which corresponds to a weak correlation (Benning, 2020).

In summary, it can be said that different identified factors have a diverging influence on the usage behavior regarding the consumption of printed travel information. The aspects of age and place of residence have a stronger influence than gender.

Traditionally, purchasing decisions are the product of various influences. It is therefore not enough to establish, that a specific factor has a significant effect. Rather, it is necessary to consider the interplay of different influences to evaluate the effectiveness. This requirement is considered in the present project by carrying out a logistic regression. For this purpose, the sample is expanded by an additional factor, the customer segment.

Customer segmentation in the company under review is automated using the Salesforce Marketing Cloud software. Basically, a distinction is made between A, B, and C customers. Different criteria flow into the segmentation. These are age, duration of the customer relationship, number of previous bookings, booking volume per person per year, and expected booking volume in the next three years. 
The logit model for logistic regression is a very robust classification procedure. It enables the explanation of a dependent binary variable. At the same time, it allows a prediction regarding the probability of occurrence of an event (Willems, 2018, p. 2). In the context of this research work, it will be used to explain participation in the campaign - and the assumed interest in printed travel literature. While a logistic regression analysis, the aim is to predict the probability of the dependent variable taking the value 1, considering the independent variables (University of Zurich UZH, 2018). Transferred to the described project, the question thus is clarified: Do the independent variables "age", "place of residence", "customer segment" or "gender" influence the probability that the dependent variable "order" takes the value "yes".

The aim of logistic regression is to predict class membership. Formally, this is a conditional probability, which according to Hude can be described as follows (Hude, 2020, 125 f.):

$$
p=P(\text { Klasse }=1 \mid(X 1, \ldots, X m)=(x 1, \ldots, x m))
$$

To ensure that the forecast values are between 0 and 1 , the so-called logit transformation for the probabilities $\mathrm{p}$ is required. This means, that in a first step, with the support of the regression function, any numerical values can initially be forecasted. These are the logits of the probabilities. In a second step, the logits are transformed back to the required probabilities. According to Hude, the logit of a probability is defined as follows (Hude, 2020, p. 126):

$$
z=\operatorname{logit}(p)=\log \left(\frac{p}{1-p}\right)
$$

The analysis of the present data set is carried out according to this approach using the software R 4.0.3 with the R package descr. The following command structure is used:

$>$ \#\#\# Logistic regression

$>\operatorname{glm} 1<-$ glm(Ordert $\sim$ Factor $1+\ldots+$ Factor 4, data $=$ df, + family $=$ binomial ()$)$

$>\operatorname{summary}(\mathrm{g} \operatorname{lm} 1)$

$>$ Call: $\operatorname{glm}($ formula $=$ Ordert $\sim$ Factor $1+\ldots+$ Factor 4 , family $=\operatorname{binomial}()$, data $=\mathrm{df}$ )

A logistic regression model, therefore, consists of independent variables or their inclusion and combination. The quality of the model is variable. For this reason, all combinations of the factors "age", "place of residence", "customer segment" or "gender" are first calculated for this study. Subsequently, the model quality is assessed according to the determined pseudo-R2. Nagelkerke's R2 is used to evaluate the models set up. The larger the Nagelkerke R2, the better the model (Willems, 2018, 8 ff.). Values from 0.5 indicate good explanatory quality (Stein, Pavetic, \& Noack, p. 62). If the Nagelgerke R-square is between 0.1 and 0.3 , the model has medium explanatory quality. If the value is less than 0.1 , the explanatory quality of the model is to be considered poor (Smigierski, 2020). Furthermore, the R2 according to McFadden is 
considered, when considering the available data. A model is considered to be well-fitted from a value of 0.2 (Willems, 2018, 8 ff.).

Table 5

\begin{tabular}{|l|r|r|r|r|}
\hline \multicolumn{1}{|c|}{ Variablen } & \multicolumn{1}{c}{ Chi2 } & \multicolumn{1}{c|}{ Sig. } & \multicolumn{1}{c|}{ Magelkerke Index } & \multicolumn{1}{c|}{ McFadden's R2 } \\
\hline All Factors & 8.179 .462 & 0,00000000 & 0.3199958 & 0.1980491 \\
\hline $\begin{array}{l}\text { Age+Customer } \\
\text { segmentation+Place of residence }\end{array}$ & 8.164 .785 & 0,00000000 & 0.3193103 & 0.197561 \\
\hline $\begin{array}{l}\text { Gender+Age+Customer } \\
\text { segmentation }\end{array}$ & 8.050 .169 & 0,00000000 & 0.3155004 & 0.1948565 \\
\hline Age+Customer segmentation & 8.030 .204 & 0,00000000 & 0.3146345 & 0.1942427 \\
\hline $\begin{array}{l}\text { Gender+Customer } \\
\text { segmentation+Place of residence }\end{array}$ & 655.412 & 0,00000000 & 0.2631981 & 0.1586947 \\
\hline Gender+Customer segmentation & 642.639 & 0,00000000 & 0.2585263 & 0.1555525 \\
\hline $\begin{array}{l}\text { Customer segmentation+Place of } \\
\text { residence }\end{array}$ & 638.922 & 0,00000000 & 0.257106 & 0.154981 \\
\hline Customer segmentation & 6.250 .801 & 0,00000000 & 0.2520255 & 0.1512007 \\
\hline Gender+Age+Place of residence & 2.741 .154 & 0,00000000 & 0.1168171 & 0.0661749 \\
\hline Age+Place of residence & 2.642 .325 & 0,00000000 & 0.1127167 & 0.06374635 \\
\hline Gender+Age & 2.53 .6837 & 0,00000000 & 0.1084405 & 0.06122303 \\
\hline Age & 2.426 .065 & 0,00000000 & 0.1038282 & 0.05851052 \\
\hline Gender+Place of residence & 5.837 .433 & 0,00000021 & 0.02576427 & 0.01408236 \\
\hline Gender & 3.212 .112 & 0,00144854 & 0.0139698 & 0.0075986 \\
\hline Place of residence & 2.307 .627 & 1,55700300 & 0.01023829 & 0.00556325 \\
\hline
\end{tabular}

\section{RESULTS}

The research presented here is based on three hypotheses. They all serve to attempt to explain customer behavior. Specifically, the aim is to identify factors that lead to the ordering of printed travel literature. One possible influencing factor could be the age of a consumer. Therefore, the influence of the factor age on ordering behavior was analyzed using the Welch t-test. For this purpose, the null hypothesis "There is no dependence between the consumption of printed travel information and the age of the consumer" was tested stochastically. The result was that no independence could be proven - the hypothesis had to be rejected. It can therefore be assumed that age has an influence on interest in printed travel information. However, the calculations only showed an effect of medium strength.

The further hypothesis H2: "The consumption of printed travel information is independent of the place of residence" was tested using a chi-square test. This revealed that no independence could be proven. Thus, it can be assumed that the place of residence has an influence on the interest in printed travel literature. The evaluation of the effect by Cramer's V, however, also indicates only a medium influence. 
Hypothesis H3: "The consumption of printed travel information is independent of gender" was tested on the same path as hypothesis $\mathrm{H} 2$ due to its nature. Again, no independence was found. However, the effect in the assessment by Cramer's V only shows a small influence.

To explain better the interest in this communication channel expressed by ordering printed travel information a logistic regression was carried out. In doing so, a further factor was included in the considerations with the affiliation to a customer segment. A total of 15 models were set up by the author, which were tested for their significance by logistic regression. The models shown in Table 1 represent all possible combinations of the available characteristics. In the first step, the models are evaluated according to Nagelkerke. This shows that many of the models have a value between 0.1 and 0.3 , which corresponds to medium quality. For this reason, an evaluation using McFadden's R2 is carried out in a second step. According to this approach, a value of 0.2 or more indicates a good fit. This value, rounded off, is achieved by three models. The best value, with a Nagelkerke Index of 0.3199958 and a Mc Fadden's R2 of 0.1980491, is achieved by the model that takes all factors into account. This is followed by the models with the factors "Age+Customer segmentations+Place of residence" and "Gender+Age+Customer segmentation". This illustrates that the characteristics of age and customer segmentation have a clearer influence on consumption. At the same time, it shows that gender and place of residence also have a noticeable effect.

\section{DISCUSSION}

It is already known that consumption can be influenced by various factors (Bieber, 2017, p. 36). Against this background, cross-national target group models have emerged in recent decades based on sociodemographic data. These are based on customer segmentation, which assigns consumers to a milieu. The assignment is associated with the assumption of particular affinities to different communication channels (Flaig \& Barth, 2018, p. 9). According to Reinecke \& Wortmann, however, customer segmentation is a form of modelling. A model, however, is always a simplified representation of reality, that aims to clarify certain aspects (Reinecke \& Wortmann, 2018, p. 195). The decisive factor for the findings is often the size of the sample (Flaig \& Barth, 2018, p. 6). For nationally or internationally active actors such as the Federal Chancellery, BMW or Reemtsma, models calculated for an entire country offer a high information content (Flaig \& Barth, 2018, p. 8). The situation can be different if regional providers or companies with a customer clientele that differs from the general population have to process a customer potential that diverges significantly from the expected customer potential. 
In this case, according to Reinecke, different media preferences and media consumption could have to be handled in a differentiated way (Reinecke \& Wortmann, 2018) - a position that is supported by this research work.

The present evaluation shows that age has an effect on interest in printed travel information. This is in line with the influence of age on travel activity already proven by Hallerbach in 2001 . However, the results differ regarding the factor "gender". While Hallerbach does not attribute any significance to gender relates travel activity, the present study does (Hallerbach, 2001, p. 415). In this context, the research design should not be disregarded. The data set on which this paper is based shows, that there is a causality between gender and ordering behavior. A statement about the willingness to travel to the destination about which information was requested cannot be derived at this point.

The relevance of the place of residence is also important for the creation of an efficient communication mix. In the present data set, this characteristic can be shown to have a low medium influence. However, within the framework of the evaluation, a distinction was only made based on the address between places of residence in cities with fewer or more than 100,000 inhabitants. This does not consider that medium-sized and smaller towns in the suburbs of metropolises can already have a metropolitan character. In addition, peculiarities in media consumption may be much more pronounced in very rural regions than in small towns.

Another important aspect is the consideration of the different customer segments. Basically, it can be assumed that customers with regular and higher sales with a tour operator have an increased travel behavior. This could explain a likewise increased interest in the consumption of printed travel literature. However, this would hide the fact, that these customer groups can also use other information channels. Against this background, the available data can also be interpreted to the effect, that discerning customers, who are willing to pay, prefer printed travel information. This is in line with BMW's experience. The manufacturer of premium cars had discontinued its customer magazine in 2018. Based on feedback from a discerning clientele, the publication, which has since been available online, is to appear in print again from 2021 (sb, 2020).

\section{CONCLUSION}

Marketing communication is undergoing major changes due to increasing digitalization. Gaiser \& Theobald note in this context that communication with stakeholders is becoming increasingly complex and dynamic. At the same time, classic communication channels retain 
their purpose. Digital communication channels are joining them (Gaiser \& Theobald, 2017, p. 142). This position, developed in 2017, is underpinned by the present work. At the same time, it becomes clear that the global changes in marketing communication are influenced in their effect by the recipients.

This paper shows that target groups that differ from the overall population can be reached more effectively with an individually tailored communication mix. In doing so, attention must be paid to efficiency. The efficiency of a communication channel depends on two factors. On the one hand, these are the contact costs, i.e. the costs associated with the use of the channel. On the other hand, it is the economic attractiveness of the target group. Efficiency for tourism SMEs arises in communication when a target group equipped with the necessary purchasing power is reached at favorable contact costs. If it is possible to achieve more efficiency than the competition at this point, then a competitive advantage can arise from marketing communication.

At the same time, this study provides approaches for further research. This could examine the significance of place of residence on the effectiveness of communication channels in more detail. In particular, differences between rural areas and large cities could be examined more closely. Likewise, a special study could analyze the interest in printed and digital travel literature in more detail. Possible questions could be the reason for choosing a print product or a test of ordering behavior under the option of print or digital media.

\section{REFERENCES}

ADAC Newsroom (2020). Einfach weiter lesen: Die neue ADAC Motorwelt: PremiumMagazin mit vielfältigen Mobilitätsthemen ab 5. März abholbereit. Retrieved from https://presse.adac.de/meldungen/adac-ev/clubleistungen/motorwelt.html

Albrecht, H., \& Walther, D. (2017). Perspektiven der Industriekultur im ländlichen Raum: Konzeption und grundlegender Ansatz zur Vermittlung des Themas Industriekultur im ländlichen Raum. Freiberg: TU Bergakademe.

Aufner, A., Breitler, D., Bruggraber, R., Gaszo, D., Geischläger, T., Heimgartner, A., . . VorelSeifert, K. (2020). Soziale Perspektiven auf die Covid-19-Phase: Eine digitale Forschungswerkstatt während der Ausgangsbeschränkungen. soziales_kapital wissenschaftliches journal österreichischer fachhochschul-studiengänge soziale arbeit, 12(24), 338-348.

Bassewitz, A., \& Ritter, G. (2001). Geschäftsprozessorganisation. Zeitschrift für wirtschaftlichen Fabrikbetrieb, 7-8.

Bauer, A. Was ist eine Cramers V? - Erklärung \& Beispiel. Retrieved from https://mathe2go.net/was-ist-eine-cramers-v-erklaerung-beispiel-tz11/

Becker, W., \& Ulrich, P. (2011). Mittelstandsforschung: Begriffe, Relevanz und Konsequenzen. Mittelstand und Mittelstandsforschung. Stuttgart: Kohlhammer. 
Beetz, J. (2016). Broschüren. Retrieved from https://norwegenerlebnisse.de/Service/ Broschuren/broschuren.html

Benning, V. (2020). Cramer's V verstehen, bestimmen und interpretieren. Retrieved from https://www.scribbr.de/statistik/cramers-v/

Beritelli, P., \& Bieger, T. (2020). Automatisierung und Personalisierung von persönlichen Dienstleistungen im Tourismus - Zum Kundenwert der persönlichen Dienstleistung. In M. Bruhn \& K. Hadwich (Eds.), Forum Dienstleistungsmanagement: Vol. 1. Automatisierung und Personalisierung von Dienstleistungen: Konzepte Kundeninteraktionen - Geschäftsmodelle (pp. 491-508). Wiesbaden: Springer Fachmedien Wiesbaden.

Bieber, A. (2017). Prekäre globale Arbeitsbedingungen der Bekleidungsherstellung und der Einfluss von Information auf das Konsumverhalten in Österreich. Universität Wien, Wien. Retrieved from https://othes.univie.ac.at/46980/

Bondareva, I., \& Zatrochová, M. (2014). Financial Support for the Development of SMEs in the Slovak Republic. Procedia - Social and Behavioral Sciences, 110, 541-548. https://doi.org/10.1016/j.sbspro.2013.12.898

Bortz, J., \& Schuster, C. (2016). Statistik für Human- und Sozialwissenschaftler: Extras online (Limitierte Sonderausgabe, 7., vollständig überarbeitete und erweiterte Auflage). Springer-Lehrbuch. Berlin, Heidelberg: Springer. Retrieved from http://www.springer.com/

Botzkowski, T. (2017). Digitale Transformation von Geschäftsmodellen im Mittelstand: Theorie, Empirie und Handlungsempfehlungen. Unternehmensführung \& Controlling. Wiesbaden: Springer Gabler. Retrieved from http://dx.doi.org/10.1007/978-3-65820333-7

Bruhn, M. (2009). Integrierte Unternehmens- und Markenkommunikation: Strategische Planung und operative Umsetzung (5.th ed.). s.1.: Schäffer-Poeschel Verlag für Wirtschaft Steuern Recht GmbH. Retrieved from http://site.ebrary.com/lib/alltitles/docDetail.action?docID=10556031

Bruhn, M. (2016). Strategische Planung und Umsetzung einer Integrierten Kommunikation: Die Anbieterperspektive. In M. Bruhn, F.-R. Esch, \& T. Langner (Eds.), Handbuch Strategische Kommunikation (pp. 103-129). Wiesbaden: Springer Fachmedien Wiesbaden.

Danielzyk, R. (2017). Klein- und Mittelstädte als Ankerpunkte in ländlichen Räumen Definitionen, Funktionen, Strategien. Neues Archiv für Niedersachsen. (2), 11-15.

Destatis.de (2011). Großstädte in Deutschland: Regionales. Retrieved from https://www.destatis.de/DE/Themen/Laender-

Regionen/Regionales/Gemeindeverzeichnis/zensus-grosstaedte-einwohner.html

Deutsche Akadmie der Technikwissenschaften, \& Körber Stiftung (2020). Technik Radar 2020: Was die Deutschen über Technik denken. München, Hamburg: Körber-Stiftung.

Dobošová, L., Hupková, D., Beňuš, O., Mihálová, V., \& Synetska, Y. (2020). Management of Receivables and their Monitoring in the Small and Medium Sized Farms in the Slovak Republic. In Faculty of Economics, University of South Bohemia in České Budějovice (Ed.), Proceedings of the 13 th International Scientific Conference INPROFORUM: Innovations, Enterprises, Regions and Management (pp. 20-27). České Budějovice: Faculty of Economics, University of South Bohemia in České Budějovice.

Döweling, A. (2019). Hindernisse und Grenzen der (Online-)Beteiligung. In A. Döweling (Ed.), Digitalisierung innerparteilicher Entscheidungsrechte (pp. 61-68). Wiesbaden: Springer Fachmedien Wiesbaden. https://doi.org/10.1007/978-3-658-27929-5_3

Enz, C. (2019a). Special requirements for corporate communications in geographically defined markets using the example of the sale of construction financing in rural areas. Balkans 
Journal of Emerging Trends in Social Sciences, 2(2), 185-193. https://doi.org/10.31410/Balkans.JETSS.2019.2.2.185-193

Enz, C. (2019b). Special requirements for corporate communications in geographically defined markets using the example of the sale of construction financing in rural areas. In B. Vuk (Ed.): International Scientific Conference ERAZ - Knowledge Based Sustainable Development, Book of Abstracts: Part of ERAZ Conference Collection (p. 9). Association of Economists and Managers of the Balkans, Belgrade, Serbia. Retrieved from https://eraz-conference.com/wp-content/uploads/2020/04/ERAZ_BoA-WEB.pdf

Enz, C. (2020a). Importance of the sales force for effective communication of SME in the B2B sector. In International Business Information Management Association (IBIMA) (Ed.), 35th IBIMA Conference on 1.-2. April 2020: Conference proceedings. Norristown, US.: IBIMA.

Enz, C. (2020b). The Decision Cause-Matrix - A tool to increase efficiency in the corporate communications of SMEs with a geographically limited business area. In Faculty of Economics, University of South Bohemia in České Budějovice (Ed.), Proceedings of the 13 th International Scientific Conference INPROFORUM: Innovations, Enterprises, Regions and Management (pp. 28-34). České Budějovice: Faculty of Economics, University of South Bohemia in České Budějovice.

Falkheimer, J., Heide, M., Nothhaft, H., Platen, S. v., Simonsson, C., \& Andersson, R. (2016). Is strategic communication too important to be left to communication professionals? Managers' and coworkers' attitudes towards strategic communication and communication professionals. Public Relations Review, 43(1), 91-101.

Fischbach, C., \& Mack, J. (2008). Mittelstandskommunikation (1. Aufl.). Konstanz: UVK Verlagsgesellschaft. Retrieved from http:/www.contentselect.com/index.php?id=bib_view\&ean=9783864961595

Flaig, B., \& Barth, B. (2018). Hoher Nutzwert und vielfältige Anwendung: Entstehung und Entfaltung des Informationssystems Sinus-Milieus ${ }^{\circledR}$. In B. Barth, B. B. Flaig, N. Schäuble, \& M. Tautscher (Eds.), Praxis der Sinus-Milieus ${ }^{\circledR}:$ Gegenwart und Zukunft eines modernen Gesellschafts- und Zielgruppenmodells (pp. 3-22). Wiesbaden: Springer VS.

Friedrichs, N., \& Winkelmann-Fietz, C. (2020). ALDI SÜD: Wandel der Unternehmenskommunikation in einem Familienunternehmen. In B. Felden, A. Hack, \& C. Hoon (Eds.), Lehrbuch. Fallstudien zum Management von Familienunternehmen: Teaching Cases für Lehre und praktische Anwendung (pp. 25-36). Wiesbaden: Springer Gabler.

Fuka, J., Vrchota, J., \& Rolínek, L. (2018). In M. Waheed, N. Ain, U. Walker, \& P. Bromwich (Eds.), Global Summit on Applied Business, Economics, and Social Science (pp. 41-58). Stockholm: Office of european academic research consortium.

Gaiser, B., \& Theobald, E. (2017). Marketingkommunikation im digitalen Wandel. In E. Theobald (Ed.), Brand Evolution: Moderne Markenführung im digitalen Zeitalter (2nd ed., pp. 125-147). Wiesbaden: Springer Gabler.

Golder, L., Jans, C., Tschöpe, S., \& Herzog, N. (2017). Warum in die Ferne schweifen .... In unsicheren Zeiten gewinnt die Schweiz als Reisedestination an Attraktivität. Bern: gfs.bern.

Graefe, L. (2017). Nutzung von Reisekatalogen im Verkaufsgespräch in deutschen Reisebüros im Jahr $2017 . \quad$ Retrieved from https:/de.statista.com/statistik/daten/studie/754046/umfrage/katalognutzung-beimverkaufsgespraech-in-deutschen-reisebueros/ 
Hallerbach, B. (2001). Tourismusvolumen und Reiseverhalten der Wohnbevölkerung des Großherzogtums Luxemburg: Tourismusvolumen und Reiseverhalten 2000. Trier: Europäisches Tourismus Institut $\mathrm{GmbH}$.

Heemsoth, F. (2019). Start-ups und junge Gründer: Praxis der Markenführung und Kommunikation. In C. Kochhan, T. Könecke, \& H. Schunk (Eds.), Marken und Startups: Markenmanagement und Kommunikation bei Unternehmensgründungen (pp. 213231). Wiesbaden: Springer Fachmedien Wiesbaden.

Heister, M. (1962). Rentabilitätsanalyse von Investitionen: Ein Beitrag zur Wirtschaftlichkeitsrechnung. Beträge zur betriebswirtschaftlichen Forschung: Vol. 17. Wiesbaden: VS Verlag für Sozialwissenschaften. Retrieved from http://dx.doi.org/10.1007/978-3-663-02894-9

Helfrich, H. (2016). Wissenschaftstheorie für Betriebswirtschaftler (1. Auflage). Wiesbaden: Springer Gabler. Retrieved from http://ebooks.ciando.com/book/index.cfm/bok_id/1900071

Herrmann, H.-P., \& Wetzel, P. (2018). Fernweh und Reiselust - Streifzüge durch die Tourismuspsychologie. Berlin, Heidelberg: Springer Berlin Heidelberg.

Hetze, K., Bögel, P. M., Emde, A., Bekmeier-Feuerhahn, S., \& Glock, Y. (2019). Online stakeholder dialogue: Quo vadis ? - An empirical analysis in German-speaking countries. Corporate Communications: An International Journal, 24(2), 248-268. https://doi.org/10.1108/ccij-01-2018-0012

Hoffmann, C., Lennerts, S., Schmitz, C., Stölzle, W., \& Uebernickel, F. (Eds.) (2016). Business Innovation: Das St. Galler Modell. Business Innovation Universität St. Gallen, Profilbereich Business Innovation. Wiesbaden: Springer Gabler. Retrieved from http://dx.doi.org/10.1007/978-3-658-07167-7

Hude, M. von der (2020). Predictive Analytics und Data Mining. Wiesbaden: Springer Fachmedien Wiesbaden.

Johann, M. (2020). Dialogorientierte Unternehmenskommunikation in den Sozialen Medien: Langfristige entwicklungen und Einflüsse auf organisationale Beziehungen. Wiesbaden: VS Verlag für Sozialwissenschaften.

Kamerar, S. (2016). Universitäten als Ideenfabriken für den Mittelstand. Retrieved from https://www.top100.de/blog/show/universitaeten-als-ideenfabriken-fuer-denmittelstand.html

Kiesenbauer, J. (2018). Kompetenzmanagement für die Unternehmenskommunikation. Wiesbaden: Springer Fachmedien Wiesbaden.

Kilian, K. (2019). BEST of Branding für Start-ups. In C. Kochhan, T. Könecke, \& H. Schunk (Eds.), Marken und Start-ups: Markenmanagement und Kommunikation bei Unternehmensgründungen (pp. 55-84). Wiesbaden: Springer Fachmedien Wiesbaden.

Kosmider, A. (1991). Controlling im Mittelstand: Eine Untersuchung der Gestaltung und Anwendung des Controllings in mittelständischen Industrieunternehmen. Schriftenreihe der Wissenschaftlichen Hochschule für Unternehmensführung Koblenz Forschung: Vol. 5. Stuttgart: Poeschel.

Kreuter, W. (2020). Die wohlige Wandlung der Ferne - Trends und Zukunftsszenarien des modernen Tourismus. In D. Pietzcker \& C. Vaih-Baur (Eds.), Ökonomische und soziologische Tourismustrends: Strategien und Konzepte im globalen Destinationsmarketing (pp. 45-55). Wiesbaden: Springer Fachmedien Wiesbaden.

Lützler, T. (2007). Internationalisierung in Global Communications - eine Einführung. In C. Langen (Ed.), Strategisch kommunizieren und führen: Profil und Qualifizierung für eine transparente Unternehmenskommunikation (2nd ed., pp. 127-136). Gütersloh: Verl. Bertelsmann Stiftung. 
Mast, C., \& Spachmann, K. (2005). Reformen in Deutschland: Wege einer besseren Verständigung zwischen Wirtschaft und Gesellschaft. Wiesbaden: VS Verlag für Sozialwissenschaften. Retrieved from http://dx.doi.org/10.1007/978-3-322-80708-3

Miosga, M., Büchs, S., Dudek, S., Klee, A., Klein, R., Odewald, C., . . Zademach, H.-M. (2020). Neuorientierung der Raumordnung in Bayern. Positionspapier aus der ARL: Vol. 117. Hannover: Verlag der ARL - Akademie für Raumentwicklung in der LeibnizGemeinschaft.

Moog, P., \& Witt, P. (2013). Mittelständische Unternehmen. Zeitschrift für Betriebswirtschaft. (4), $1-4$.

Müller, P. (2011). Über die Notwendigkeit und den Nutzen proefssioneller Kommunikation. „Und was bringt das Ganze?“. In P. Müller \& T. Lüdeke (Eds.), Kommunikation im Mittelstand: Unternehmerische Herausforderungen erfolgreich meistern (pp. 10-16). Meckenheim: DIHK-Verlag.

Pfannstiel, M. A., Da-Cruz, P., \& Rederer, E. (Eds.) (2020). Digitale Transformation von Dienstleistungen im Gesundheitswesen VII: Impulse für die Pharmaindustrie (1. Auflage 2020). Wiesbaden: Springer Gabler.

Pfeil, S. (2016). Werteorientierung und Arbeitgeberwahl im Wandel der Generationen (Dissertation). Springer Fachmedien Wiesbaden GmbH.

Pfohl, H.-C., \& Arnold, U. (Eds.) (2006). Betriebswirtschaftslehre der Mittel- und Kleinbetriebe: Größenspezifische Probleme und Möglichkeiten zu ihrer Lösung (4., völlig neu bearb. Aufl.). Management und Wirtschaft Praxis: Vol. 44. Berlin: Schmidt.

Philipp, T. (2017). Netzwerkforschung zwischen Physik und Soziologie. Netzwerkforschung. Wiesbaden: Springer Fachmedien Wiesbaden.

Rauch, K. (2019). Informationsabstufung und -verknüpfung im Konzernlagebericht: Eine empirische analyse der Risikoberichterstattung. Auditing and Accounting Studies. Wiesbaden: Springer Gabler.

Reichhard, S. (2019). Content Marketing für Regionalbanken: So können Genossenschaftsbanken und Sparkassen Kunden gewinnen, binden und begeistern. Wiesbaden: Springer Fachmedien Wiesbaden.

Reinecke, S., \& Wortmann, C. (2018). Google Knows it Better? Ein Plädoyer für integrierte und wider ausschließlich verhaltensorientierte Ansätze zur strategischen Kundensegmentierung. In B. Barth, B. B. Flaig, N. Schäuble, \& M. Tautscher (Eds.), Praxis der Sinus-Milieus ${ }^{\circledR}:$ Gegenwart und Zukunft eines modernen Gesellschafts- und Zielgruppenmodells (pp. 193-208). Wiesbaden: Springer VS.

Sakai, T. (2016). Two Sample T-tests for IR Evaluation. In R. Perego, F. Sebastiani, J. Aslam, I. Ruthven, \& J. Zobel (Eds.), Proceedings of the 39th International ACM SIGIR conference on Research and Development in Information Retrieval - SIGIR '16 (pp. 1045-1048). New York, New York, USA: ACM Press. https://doi.org/10.1145/2911451.2914684

Sb (2020). BMW-Magazin kehrt zurück. new business. Retrieved from https://www.newbusiness.de/kommunikation/detail.php?rubric=KOMMUNIKATION\&nr=762708

Scheu, A., \& Schedifka, T. (2018). Wissenschaftskommunikation im Netz. Eine explorative Studie zurNutzung webbasierter sozialer Kommunikationskanäle. In L. M. Hagen, C. Lüthje, F. Ohser, \& C. Seifert (Eds.), Forschungsfeld Wissenschaftskommunikation: Band 1. Wissenschaftskommunikation: Die Rolle der Disziplinen (1st ed., pp. 177-213). Baden-Baden: Nomos.

Schlager, S. (2020). Zur Erforschung des Zusammenhangs zwischen Sprachkompetenz und Mathematikleistung: Oberflächlichkeit als potenzieller Mediator. Wiesbaden: Springer Fachmedien Wiesbaden. 
Škodová Parmová, D., Líšková, Z., \& Kain, R. (2018). Cross-border regions as supporting structures for raising competitiveness in Europe. In Association of Economists and Managers of the Balkans (Ed.), Fourth international scientific conference ERAZ 2018: Knowledge based sustainable economic development (pp. 65-78). Sofia.

Smigierski, J. (2020). Logistische Regression in SPSS. Retrieved from https://www.beratungstatistik.de/statistik-beratung-infos/spss-tips/logistische-regression-spss/

Spielhagen, E. (1996). Stattfernsehen - Stadtfernsehen: Lokale TV-Kanäle in Brandenburg eine Untersuchung von 15 in Brandenburger Kabelnetzen veranstalteten Stadtkanalprogrammen. Schriftenreihe der MABB, Medienanstalt Berlin-Brandenburg: Vol. 4. Berlin: Vistas-Verlag.

Statista Research Department (2015). Wie lange nutzt Ihr (Dienstleistungs-)Unternehmen bereits elektronische Kataloge? Retrieved from https://de.statista.com/statistik/daten/studie/214133/umfrage/nutzung-vonelektronischen-katalogen-durch-dienstleistungsunternehmen-im-b2b/

Stein, P., Pavetic, M., \& Noack, M. Multivariate Analyseverfahren. Duisburg: Universität Duisburg Essen.

Störk-Biber, C., Hampel, J., Kropp, C., \& Zwick, M. (2020). Wahrnehmung von Technik und Digitalisierung in Deutschland und Europa: Befunde aus dem TechnikRadar. HMD Praxis der Wirtschaftsinformatik. Advance online publication. https://doi.org/10.1365/s40702-020-00587-x

Ternès, A., Klenke, B., Jerusel, M., \& Schmidtbleicher, B. (2017). Integriertes Betriebliches Gesundheitsmanagement: Sensibilisierungs-, Kommunikations- und Motivationsstrategien. Wiesbaden: Springer Gabler. Retrieved from http://dx.doi.org/10.1007/978-3-658-14640-5

Tieschky, C. (2010, May 19). Der gute Riese. Süddeutsche Zeitung. Retrieved from https://www.sueddeutsche.de/wirtschaft/adac-motorwelt-der-gute-riese-1.898122

Universität Zürich UZH (2018). Logistische Regressionsanalyse. Methodenforschung. Zürich: Universität Zürich UZH. Retrieved from https://www.methodenberatung.uzh.ch/de/datenanalyse_spss/zusammenhaenge/lreg.htm 1

Visit Sweden GmbH (2020). Broschüren. Retrieved from https://visitsweden.de/uberschweden/broschuren-bestellen/

Volkswagen AG (2018, November 26). Volkswagen will Marketingeffizienz deutlich steigern [Press release]. Wolfsburg. Retrieved from https://www.volkswagennewsroom.com/de/pressemitteilungen/volkswagen-will-marketingeffizienz-deutlichsteigern-4411

Voß, O. (2018, July 9). Otto-Katalog wird eingestellt. Der Tagesspiegel. Retrieved from https://www.tagesspiegel.de/wirtschaft/versandhandel-otto-katalog-wirdeingestellt/22771476.html

Vrchota, J., Volek, T., \& Novotná, M. (2019). Factors Introducing Industry 4.0 to SMES. Social Sciences, 8(5), 130. https://doi.org/10.3390/socsci8050130

Walter, U. (2017a). Qualitätsstandards im BGM. In B. Badura (Ed.), Arbeit und Gesundheit im 21. Jahrhundert: Mitarbeiterbindung durch Kulturentwicklung (pp. 109-125). Berlin: Springer Gabler.

Walter, U. (2017b). Qualitätsstandards im BGM. In B. Badura (Ed.), Arbeit und Gesundheit im 21. Jahrhundert: Mitarbeiterbindung durch Kulturentwicklung (pp. 109-125). Berlin: Springer Gabler.

Walter, U. (2017c). Qualitätsstandards im BGM. In B. Badura (Ed.), Arbeit und Gesundheit im 21. Jahrhundert: Mitarbeiterbindung durch Kulturentwicklung (pp. 109-125). Berlin: Springer Gabler. 
Walther, B. (2019, October 11). Welch-Test in SPSS durchführen. Retrieved from https://www.bjoernwalther.com/welch-test-in-spss-durchfuehren/

Weber, F., \& Kühne, O. (2015). Bausteine der Regionalentwicklung - eine Einführung. In O. Kühne \& F. Weber (Eds.), RaumFragen. Bausteine der Regionalentwicklung (pp. 1-10). Wiesbaden: Springer VS. https://doi.org/10.1007/978-3-658-02881-7_1

Weber, S. M., Göhlich, M., Schröer, A., \& Engel, N. (2017). Forschungsstrategien und Methodologien der Organisationspädagogik: Eine Einführung. In M. Göhlich, A. Schröer, \& S. M. Weber (Eds.), Springer Reference. Handbuch Organisationspädagogik (pp. 1-7). Wiesbaden: Springer.

White, P., Redford, P., \& Macdonald, J. (2019). An example motivated discourse of the independent samples t-test and the Welch test. Teaching Resource. Bristol: UWE Bristol - University of the West of England.

Wilke, J. (2009a). Die zweite Säule des "dualen Systems": Privater Rundfunk. In Bundeszentrale für politische Bildung (Ed.), Beilage zur Wochenzeitung Das Parlament: 9-10. Aus Politik und Zeitgeschichte: Öffentlich-rechtlicher Rundfunk (pp. 12-19). Berlin.

Wilke, J. (2009b). Die zweite Säule des "dualen Systems": Privater Rundfunk. In Bundeszentrale für politische Bildung (Ed.), Beilage zur Wochenzeitung Das Parlament: 9-10. Aus Politik und Zeitgeschichte: Öffentlich-rechtlicher Rundfunk (pp. 12-19). Berlin.

Wilke, J. (2009c). Die zweite Säule des "dualen Systems": Privater Rundfunk. In Bundeszentrale für politische Bildung (Ed.), Beilage zur Wochenzeitung Das Parlament: 9-10. Aus Politik und Zeitgeschichte: Öffentlich-rechtlicher Rundfunk (pp. 12-19). Berlin.

Will, R. (2018). Corporate Design als effektives Mittel zur Stärkung der Marke SEWEURODRIVE. In C. Baumgarth (Ed.), B-to-B-Markenführung: Grundlagen - Konzepte Best Practice (2nd ed., 523-). Wiesbaden: Springer Gabler.

Willems, L. (2018). Logistische Regression. Trier: Hochschule Trier.

Winkler, L. (2020). Organisationskommunikation im Mittelstand: Genese und spezifik der kommunikation mittelstndischer Industrieunternehmen. Wiesbaden: Springer VS.

Zehrer, A. (2020). Structure, significace and challenges of fimily firms in community-type Alpine tourism destinations. In H. Pechlaner (Ed.), Entrepreneurial Management und Standortentwicklung, Perspektiven für Unternehmen und Destinationen. Destination und Lebensraum: Perspektiven touristischer Entwicklung : 20 Jahre Tourismusforschung von Eurac Research (pp. 24-38). Wiesbaden: Springer Gabler.

Zerfaß, A. (2006). Kommunikations-Controlling.: Methoden zur Steuerung und Kontrolle der Unternehmenskommunikation. In B. Schmid \& B. Lyczek (Eds.), Unternehmenskommunikation: Kommunikationsmanagement aus Sicht der Unternehmensführung (pp. 431-465). Wiesbaden: Gabler Verlag / GWV Fachverlage GmbH Wiesbaden.

Zerfaß, A. (2014). Unternehmenskommunikation und Kommunikationsmanagement: Strategie, Management und Controlling. In A. Zerfaß \& M. Piwinger (Eds.), Springer NachschlageWissen. Handbuch Unternehmenskommunikation: Strategie - Management - Wertschöpfung (2nd ed., pp. 21-79). Wiesbaden: Springer Gabler.

Zerfaß, A., Bentele, G., Schwalbach, J., \& Sherzada-Rohs, M. (2018). Unternehmenskommunikation aus der Perspektive von Top-Managern und Kommunikatoren. In O. Hoffjann \& R. Seidenglanz (Eds.), Allmächtige PR, ohnmächtige PR: Die doppelte Vertrauenskrise der PR (pp. 197-224). Wiesbaden: Springer Fachmedien Wiesbaden. 
Zerfaß, A., Fink, S., \& Winkler, L. (2015). Mittelstandskommunikatin 2015: Studie zum Stellenwert und Einsatz von Unternehmenskommunikation im Deutschen Mittelstand (Study). Universität Leipzig, Leipzig. Retrieved from https:/faehrmannschaft.de/wpcontent/uploads/2015/06/Studie-Mittelstandskommunikation-2015-Ergebnisbericht.pdf

Zerfaß, A., \& Piwinger, M. (2014). Unternehmenskommunikation als Werttreiber und Erfolgsfaktor. In A. Zerfaß \& M. Piwinger (Eds.), Springer NachschlageWissen. Handbuch Unternehmenskommunikation: Strategie - Management - Wertschöpfung (2nd ed., pp. 1-18). Wiesbaden: Springer Gabler.

Zerfaß, A., \& Pleil, T. (2017). Einleitung. In A. Zerfaß \& T. Pleil (Eds.), PR-Praxis: Band 7. Handbuch Online-PR: Strategische Kommunikation in Internet und Social Web (2nd ed., pp. 9-16). Köln: Herbert von Halem Verlag. 